\title{
Study on the Prevention and Control of Fe and Mn Pollution by Resistant Mixed Bacteria in Simulated Mining Area
}

\author{
Tianxin $\mathrm{Li}^{*}(* *)$, Fang Zhang*(**)† and Minjie Zhang* \\ *School of Energy and Environmental Engineering, University of Science and Technology Beijing, Beijing, 100083 \\ PR China \\ **Beijing Key Laboratory of Resource-oriented Treatment of Industrial Pollutants, Beijing, 100083, PR China \\ †Corresponding author: Fang Zhang; b20180082@xs.ustb.edu.cn
}

Nat. Env. \& Poll. Tech.

Website: www.neptjournal.com

Received: $21-12-2020$

Revised: $12-03-2021$

Accepted: 10-04-2021

Key Words:

Iron pollution

Manganese pollution

Coal mine area

Fe and Mn resistant

microorganisms

Pollution control

\section{ABSTRACT}

By simulating the mining environment, the potential of the selected mixed bacteria (Pseudomonas putida, Lysinibacillus xylanilyticus, Lysinibacillus macroides, Bacillus simplex, Brevibacillus agri) to control Fe and Mn pollutants in mining environment were explored. The results showed that the selected bacteria could inhibit the release of $\mathrm{Fe}$ and $\mathrm{Mn}$ from ore into the aquifer, and the inhibition effect on Mn was significantly stronger than that on Fe. At the same time, these processes also have a certain degree of impact on the external environment, including the gradual increase of $\mathrm{pH}$, the gradual decrease of oxidation-reduction potential, and the decrease of dissolved oxygen concentration. The changes of these external environmental factors will once again directly affect the degradation and immobilization of $\mathrm{Fe}$ and $\mathrm{Mn}$. The selected mixed bacteria can also enhance the adsorption of free Fe and $\mathrm{Mn}$, improve the adsorption efficiency and capacity of $\mathrm{Fe}$ and $\mathrm{Mn}$, and slow down the desorption of $\mathrm{Fe}$ and $\mathrm{Mn}$ to water.

\section{INTRODUCTION}

Coal plays an important role in energy generation, and approximately $27 \%$ of the world's energy consumption originates from the incineration of coal (Bhuiyan et al. 2010). Industrial production and exploitation of mineral resources are important sources of heavy metal pollution in soil (Bermudez et al. 2012). Heavy metals in coal or coal wastes are released and accumulated in the soil through various processes (leaching, weathering, combustion, and biological reaction) (Shafer et al. 2012, Zhou et al. 2014). Coal mining has resulted in $\mathrm{Fe}$ and $\mathrm{Mn}$ contamination in mining areas, which has become a key issue in terms of soil ecological environment protection (Guo et al. 2012). By examining heavy metals in mine drainage soil and surrounding farmland in northern Bangladesh, Bhuiyan et al. (2010) discovered that Mn came from human sources, particularly coal mining activities. Zhang \& Wang (2009) found that the oxidation of heavy metal sulfide was the main way for coal gangue to release $\mathrm{Fe}$ and $\mathrm{Mn}$ into the environment. Wang et al. (2005) found that Aha Lake has been polluted by coal mine wastewater for a long time, and $\mathrm{Fe}$ and $\mathrm{Mn}$ were brought into the lake through this wastewater. Herndon et al. (2019) found that mine spoil continues to produce Mn contamination. Liu et al. (2020) showed that Fe and Mn pollution of the surface water environment around the centralized mining area of Guizhou Province mainly comes from abandoned coal mines. A high Fe and Mn content will have a significant impact on people's lives and production (Sorensen et al. 2010, Vazquez et al. 2014, Zerling et al. 2008).

$\mathrm{Fe}$ and $\mathrm{Mn}$ belong to transition metal elements and have similar properties. The common methods to remove $\mathrm{Fe}$ and $\mathrm{Mn}$ in groundwater include chemical precipitation (Patil et al. 2016), reverse osmosis (Fan et al. 2018), ion exchange (Zhang et al. 2008), and so on. Super enrichment plants are the key technical direction for Fe and Mn soil remediation (Kovácik et al. 2014), chelating agents (Hauck et al. 2006), and microbial remediation (Sasaki 2009). The emerging microbial oxidation method has become a key research direction (Wang et al. 2012). Compared with animals or plants growing in the same soil, microbial activity is more sensitive to heavy metals (Giller et al. 1998). Zhang et al. (2017) tried to use Fusarium oxysporum sp. ZHH2-starchalfalfa to repair the polluted soil in the coal mine area, and achieved good removal effect. Hou et al. (2020) isolated a microbial mixture, which can remove $99.8 \%$ and $98.6 \%$ of $\mathrm{Fe}$ and $\mathrm{Mn}$ in an acid mine drainage system, respectively. Krishnan et al. (2007) found that autotrophs and heterotrophs work in tandem, and can mitigate the concentration of $\mathrm{Mn}$ and related metals in mangrove sediments. Ling et al. (2011) 
screened out three strains of microorganism with strong manganese resistance, and the removal rate was more than $90 \%$ when the concentration of $\mathrm{Mn}^{2+}$ was $200 \mathrm{mg} . \mathrm{L}^{-1}$.

At present, the $\mathrm{Fe}$ and $\mathrm{Mn}$ resistant microbial resources are very limited, and the microbial resources have been found to be less applied in the actual remediation process (Chen et al. 2017). The identified potential organism for bioconcentration/biotransformation/biosorption is of great significance for the remediation of metals in a polluted environment (Sharma \& Fulekar 2009). The development of the Yimin opencut coal mine in Inner Mongolia of China has caused serious damage to the local ecology (Guo et al. 2014). The soil microorganism used in this paper was derived from directional domestication of $\mathrm{Fe}$ and $\mathrm{Mn}$ tolerance in the Yimin opencut coal mine, and the potential of the selected mixed bacteria for the prevention and control of $\mathrm{Fe}$ and $\mathrm{Mn}$ pollution was discussed by simulating the internal environment of the mining area. It can provide some help for the study of microorganisms to assist in the restoration of coal mine ecological environment, and the prevention and control of Fe and Mn pollution (Cui et al. 2010).

\section{MATERIALS AND METHODS}

\section{Study Area}

Yimin open-pit coalfield $\left(119^{\circ} 39^{\prime} 20^{\prime \prime}-119^{\circ} 46^{\prime} 35^{\prime \prime} \mathrm{E}, 48^{\circ} 33^{\prime}\right.$ $00^{\prime \prime}-48^{\circ} 36^{\prime} 24^{\prime \prime} \mathrm{N}$ ) is located in the alluvial plain of the middle reaches of Yimin River in the north of Inner Mongolia, under the jurisdiction of Hulun Buir city. The most important basic feature of its hydrogeological conditions is that the coal seam is the main aquifer and strong conductive aquifer.

\section{Experimental Design}

Two immersion conditions, bacteria mixed solution, and blank medium were used to carry out the immersion test of Fe and $\mathrm{Mn}$ ores in the coal seam aquifer of the mining area to explore the response mechanism of the Fe and Mn immersion process of minerals to the selected bacteria. At the same time, $\mathrm{pH}$, oxidation-reduction potential (ORP), and dissolved oxygen (DO) of leaching solution were determined to explore the influence on external environmental factors.

To study the interaction between the adsorption and desorption behavior of $\mathrm{Fe}$ and $\mathrm{Mn}$ in the soil medium of the mining area and the selected bacteria, the soil samples of the mining area were used to make the soil column, and the selected mixed bacteria were fixed in it. Different concenb trations of Fe and Mn solutions were prepared to carry out the leaching test on the soil column, dynamically simulating the migration process of $\mathrm{Fe}$ and $\mathrm{Mn}$ in the high background soil medium. The leaching test of Fe solution was divided into three rounds, which were irrigated with the leaching solution with Fe concentration of $5 \mathrm{mg} . \mathrm{L}^{-1}, 10 \mathrm{mg} . \mathrm{L}^{-1}$, and 20 $\mathrm{mg} . \mathrm{L}^{-1}$ respectively. Each round of leaching test included the adsorption stage (6 days) and the desorption stage (4 days). The leaching experiments were carried out with Mn concena trations of $5 \mathrm{mg} . \mathrm{L}^{-1}, 10 \mathrm{mg} . \mathrm{L}^{-1}$, and $20 \mathrm{mg} . \mathrm{L}^{-1}$ respectively. Each round of leaching test included the adsorption stage (6 days) and the desorption stage (3 days).

At the end of each adsorption experiment cycle, the desorption test was completed by rinsing with deionized water with $\mathrm{pH}=5.0$ until the concentration of $\mathrm{Fe} / \mathrm{Mn}$ in the penetration liquid drops to $0 \mathrm{mg} . \mathrm{L}^{-1}$.

\section{Research Method}

The concentration of Fe in the solution was determined by the MR method. Fe was reduced to ferrous ion by Fe MR reagent and then reacted with 1,10-Phenanthroline to form an orange compound. The color produced by the reaction reflects the concentration of $\mathrm{Fe}$ in the water sample, which can be directly measured by the photometer (Palintest 8000).

The concentration of $\mathrm{Mn}$ in the test solution was deh termined by potassium permanganate spectrophotometry (National Standard of the People's Republic of China 1990), and it was calculated according to the regression equation obtained from the standard curve of the absorbance ratio of the measured sample.

\section{Source and Treatment of Experimental Materials}

Soil samples from Yimin open-pit mine will be used for isolation and screening of $\mathrm{Fe}$ and $\mathrm{Mn}$ resistant bacteria. After two months of irrigation and domestication of $\mathrm{Fe}$ and $\mathrm{Mn}$ solution, it was determined that the selected mixed bacteria in this study were: Pseudomonas putida, Lysinibacillus xylanilyticus, Lysinibacillus macroides, Bacillus simplex, and Brevibacillus agri. Five strains were purified and cultured in a $4{ }^{\circ} \mathrm{C}$ refrigerator for cold storage. $2 \mathrm{~mL}$ of each pure microorganism solution was inoculated into beef extract peptone culture medium, which was cultured at constant temperature for $18 \mathrm{hr}$ at $30^{\circ} \mathrm{C}$, and then used for the experiment after activation.

The Fe and Mn ore used in the leaching test was provided by the State Key Laboratory of Biochemistry, Institute of Process Engineering, Chinese Academy of Sciences, with a particle size of 400 mesh.

In the leaching experiment, the soil of $50 \mathrm{~cm}$ below the surm face near the Yimin open-pit coal mine, which is not affected by Fe and Mn pollution, was selected and preserved naturally after being dried. The sample soil and quartz sand were mixed in a ratio of 2:1 to increase the porosity of the leaching test soil. The grain size of quartz sand is 100-200 mesh. 


\section{RESULTS AND DISCUSSION}

\section{Immersion Experiment}

With the increase of the immersion time, the concentrations of $\mathrm{Fe}$ and $\mathrm{Mn}$ in the solution under both immersion conditions were increasing. In addition, the precipitation rate of Fe and Mn was gradually slowing down (Fig.1). Compared with the two immersion conditions, the concentrations of $\mathrm{Fe}$ and $\mathrm{Mn}$ in the blank medium solution increased faster. On the 30th day, the concentrations of Fe and $\mathrm{Mn}$ in the microorganism immersion solution decreased by $4 \%$ and $48.6 \%$ respectively compared with those in the blank medium. The mixed microorganism liquid can slow down the increase of $\mathrm{Fe}$ and $\mathrm{Mn}$ concentrations in simulated coal mine aquifer.

The action mechanism of $\mathrm{Fe}$ and $\mathrm{Mn}$ resistant microorganisms on $\mathrm{Fe}$ and $\mathrm{Mn}$ is basically similar, which is mainly reflected in two aspects: Fe and Mn resistant microorganisms can actively promote the enrichment of various elements in cells and generate active compounds, which have strong control on the ORP of the surrounding environment. In addition, Fe and Mn resistant microorganisms can also produce enzymes or other specific factors to catalyze related oxidation reactions.

The $\mathrm{pH}$ of the two immersion solutions increased slowly with the increase of time (Fig.2a). Compared with the blank medium, the $\mathrm{pH}$ of immersion solutions was slightly higher. When the time reaches 23 days, the $\mathrm{pH}$ of the two conditions was basically the same, the average value was 9.0. The $\mathrm{pH}$ gradually increased from 23 to 31 days, and it remained essentially synchronized. The $\mathrm{pH}$ level has a significant impact on the removal of $\mathrm{Fe}$ and $\mathrm{Mn}$. The increase or decrease of $\mathrm{pH}$ can reflect the influence of microorganisms on $\mathrm{Fe}$ and $\mathrm{Mn}$ (An et al. 2006). Generally speaking, the higher the $\mathrm{pH}$ is, the faster the oxidation speed of $\mathrm{Fe}^{2+}$ and $\mathrm{Mn}^{2+}$, and the easier the removal of $\mathrm{Fe}$ and $\mathrm{Mn}$. When the $\mathrm{pH}$ is more than 5.5 and the $\mathrm{pH}$ is increased by 1.0 , the oxidation reaction speed of $\mathrm{Fe}^{2+}$ will increase by 100 times, and the oxidation reaction speed of $\mathrm{Mn}^{2+}$ will also increase significantly when the pH is more than 9.0 (Chen et al. 2015, Yu et al. 2004). From the viewpoint of microbiology, the isoelectric point of the microorganism is at $\mathrm{pH}=2-5$. In general, the surface charge of microorganisms living in a neutral and alkaline environment is always negatively charged, which

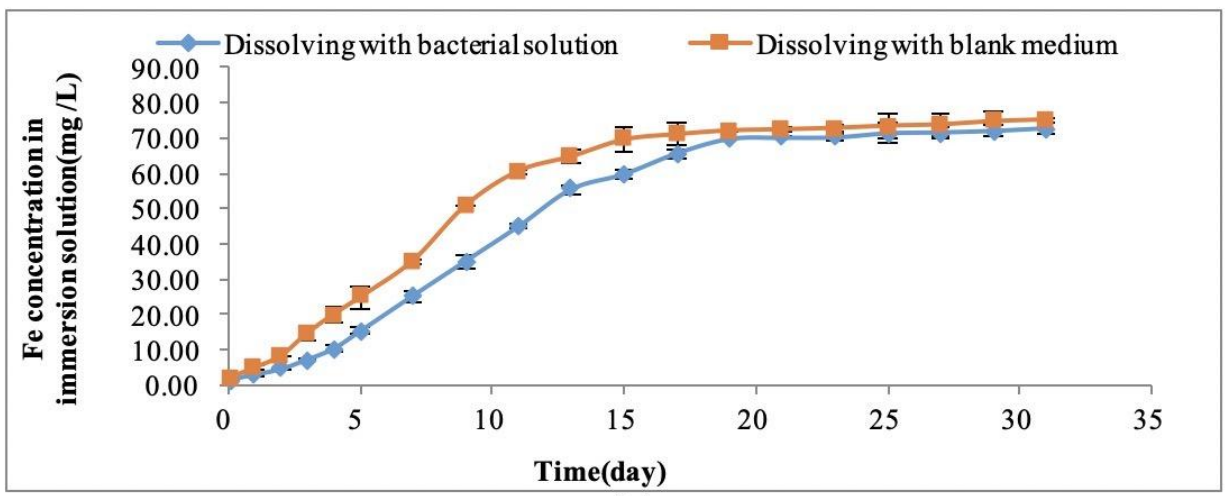

(a)

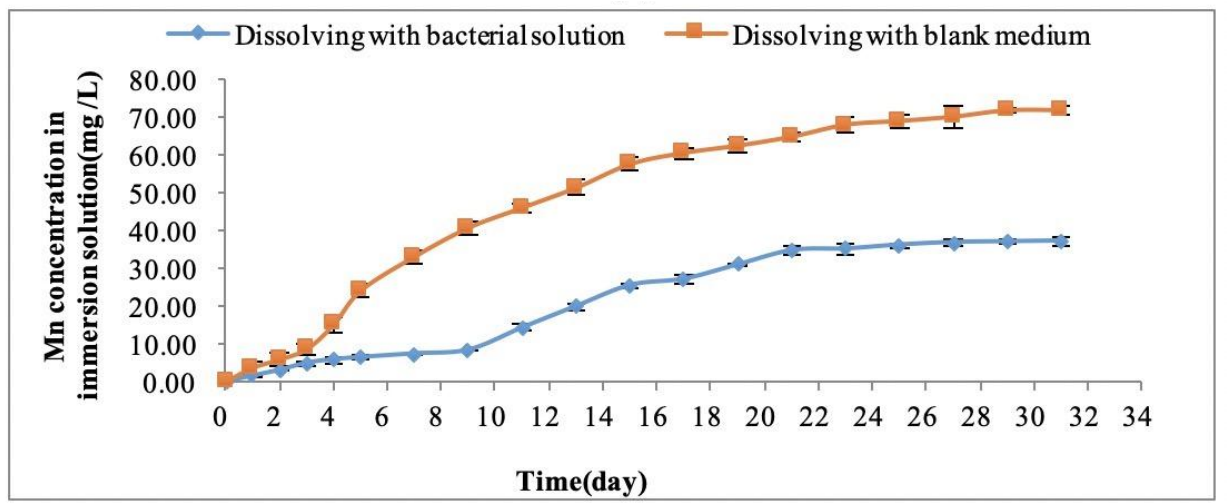

(b)

Fig. 1: Changes of $\mathrm{Fe}$ and $\mathrm{Mn}$ concentrations in immersion solution with time. 
is conducive to the adsorption of cations in water, such as $\mathrm{Fe}^{2+}, \mathrm{Mn}^{2+}$, and so on. When the $\mathrm{pH}$ of the microorganism culture environment varies, the surface charge of the microorganisms changes as well, affecting cation absorption and reducing bacteria' ability to utilize these ions. In addition, if the $\mathrm{pH}$ in the environment is too high or too low, it will affect the catalytic ability of the microbial enzyme system (Kulandaivel et al. 2015). The biological enzyme can only play its maximum activity under the optimal $\mathrm{pH}$ condition, and the extreme $\mathrm{pH}$ condition will reduce the microbial enzyme activity, thus affecting the biochemical process in the biological cells, and even cause the destruction and death of the microbial cells.

ORP of immersion solution decreased slowly with the increase of time (Fig.2b). Compared with the blank medium, the ORP of the microorganism immersion solution was slightly higher. ORP of the microorganism immersion solution and the blank medium decreased to $0 \mathrm{mV}$ for 21 days and 28 days, respectively. On day 31 , ORP in the solution both reached the lowest. The form of Mn in nature was closely related to ORP. In the water with neutral $\mathrm{pH}$, the ORP of $\mathrm{Mn}^{2+}$ is generally less than $400 \sim 450 \mathrm{mv}$. When looking at Mn removal from the perspective of oxidationreduction, the objective is to maximize the ORP of the water environment to the point where $\mathrm{Mn}^{2+}$ can no longer exist in a stable state. The groundwater environment in the Yimin Coalfield has strong reducibility, which is very unfavorable to the oxidation reaction of $\mathrm{Mn}^{2+}$, resulting in the high concentration of $\mathrm{Mn}^{2+}$ in water.

DO of the immersion solution decreased sharply with the increase of time (Fig.2c). DO of microbial immersion solution and blank medium immersion solution decreased to $0.03 \mathrm{mg} . \mathrm{L}^{-1}$ on the $4^{\text {th }}$ and $9^{\text {th }}$ day respectively, and then remained unchanged. A decrease in DO generally leads to a decrease in ORP. Because the selected bacteria were aerobic microorganisms, and the conical bottle mouth was sealed with a cotton cloth during the cultivation process, microorganisms will consume a lot of DO until it reaches the equilibrium state.

\section{Leaching Experiment}

The concentration of $\mathrm{Fe}$ in penetration liquid increased with the increase of penetration liquid volume (Fig. 3a). In general, compared with the soil column without microbial

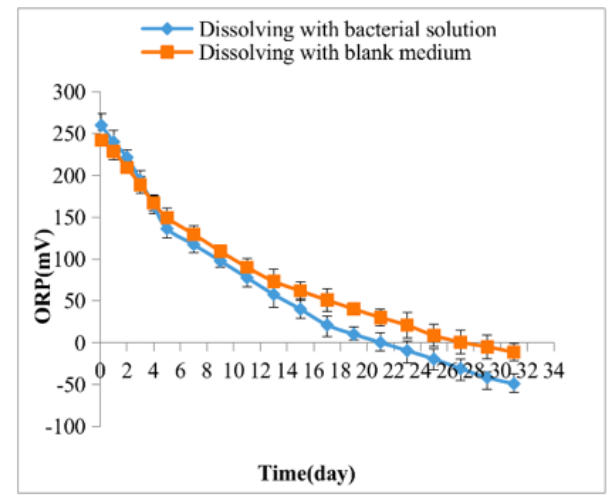

(b)

(a)

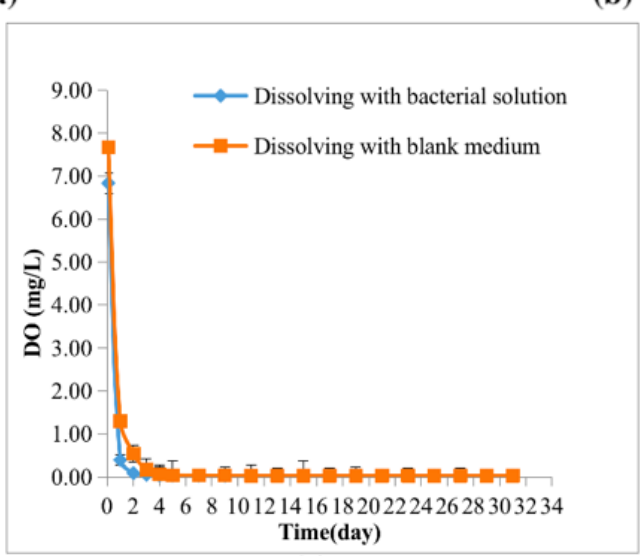

(c)

Fig. 2: Changes of $\mathrm{pH}, \mathrm{ORP}$ and DO in solution with time. 


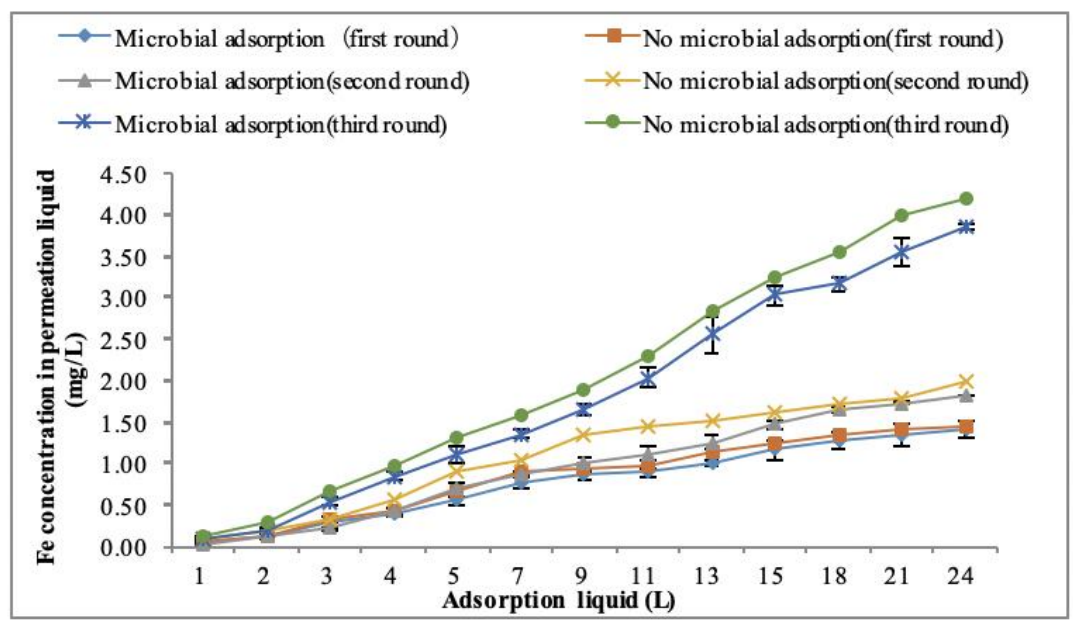

(a)

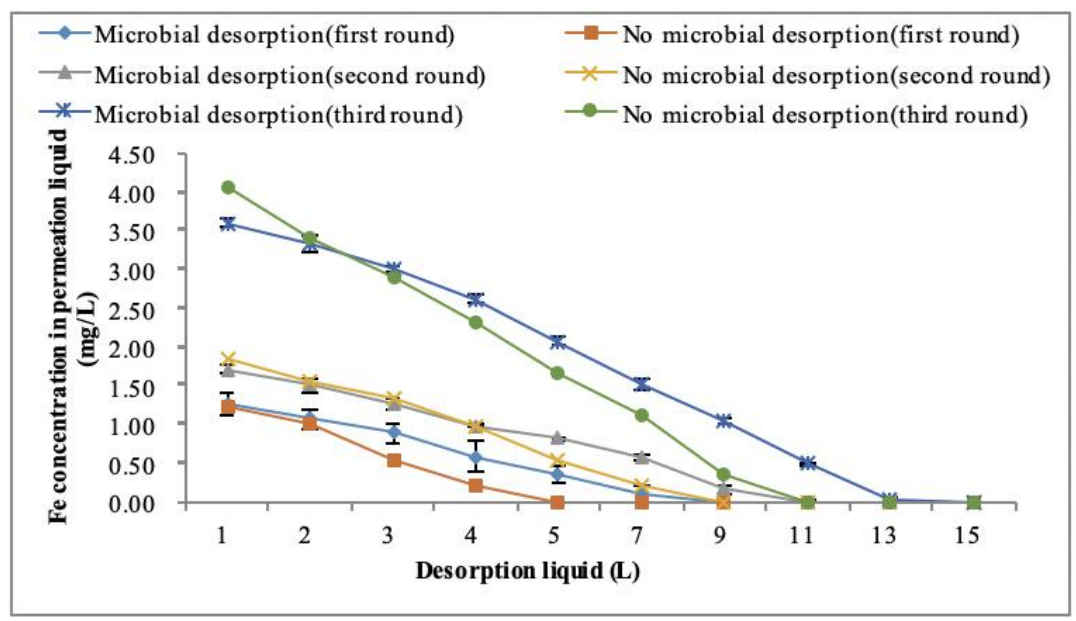

(b)

Fig. 3: Variation of Fe concentration in leaching liquid during adsorption and desorption.

assistance, the soil column with microbial assistance has a stronger adsorption capacity for $\mathrm{Fe}$ and a lower concentration of Fe in the penetration liquid. In the first round of the adsorption experiment, with the help of the selected bacteria, the adsorption capacity of the soil column to Fe increased by $2.82 \%$. In the second round of adsorption experiment, with the help of the selected bacteria, the adsorption capacity of soil column to Fe increased by $9.89 \%$, and in the third round of adsorption experiment, with the help of the selected bacteria, the adsorption capacity of soil column to Fe increased $9.07 \%$.

The main reason for this phenomenon was that the adsorption of heavy metal ions depends on the surface energy and local negative charge of soil particles. With the help of the selected bacteria, the adsorption of heavy metal ions in soil includes not only physical adsorption but also biological adsorption of microorganisms and adsorption of microbial metabolites.

Furthermore, the experiment revealed that reaching the saturation state of Fe adsorption in the leaching solution was difficult. The reason may be that Fe will form $\mathrm{Fe}$ $(\mathrm{OH})_{3}$ colloid and $\mathrm{Fe}(\mathrm{OH})_{2}$ precipitate in the environment when $\mathrm{pH}>3.5$, and then stay in the soil. To simulate the neutral and alkalescent mining system, the $\mathrm{pH}$ value of the leaching solution was not adjusted to an acidic environment. Therefore, $\mathrm{Fe}$ in the leaching solution was largely retained in the soil column during the leaching process, which also explained the phenomenon of low concentration of $\mathrm{Fe}$ in the penetration liquid.

The concentration of $\mathrm{Fe}$ in the penetration liquid decreased with the desorption process, and in this experiment, $\mathrm{Fe}$ adsorbed in the three-round desorption test soil column 


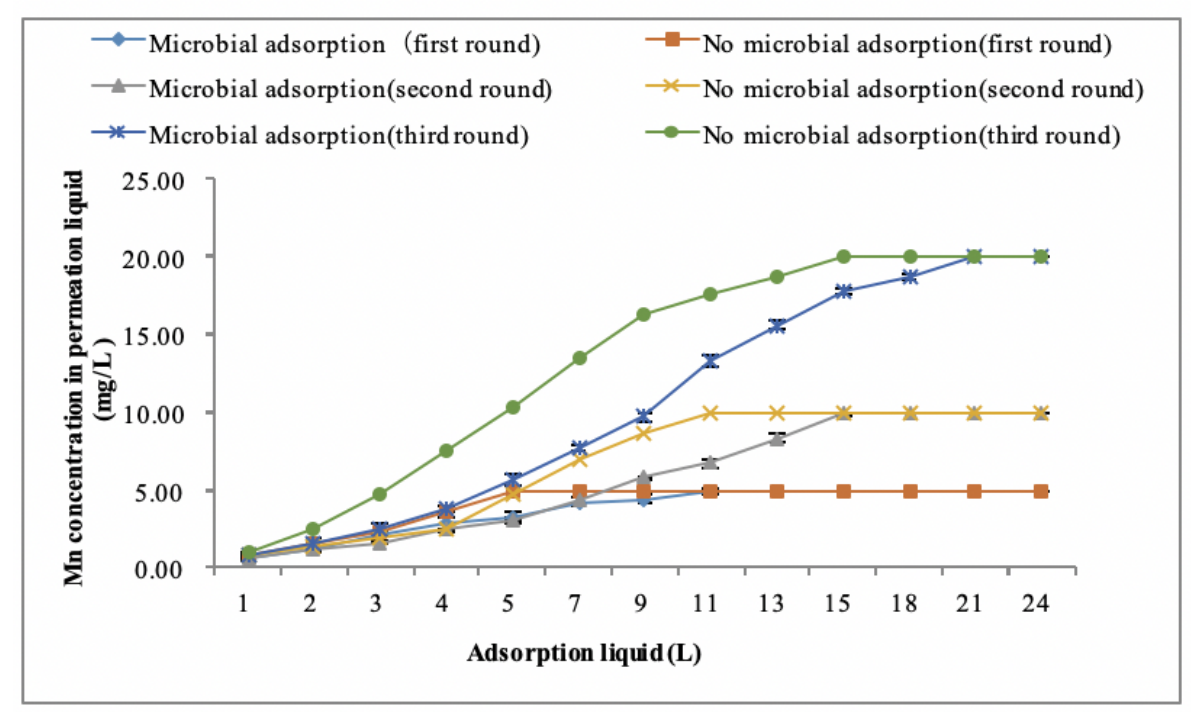

(a)

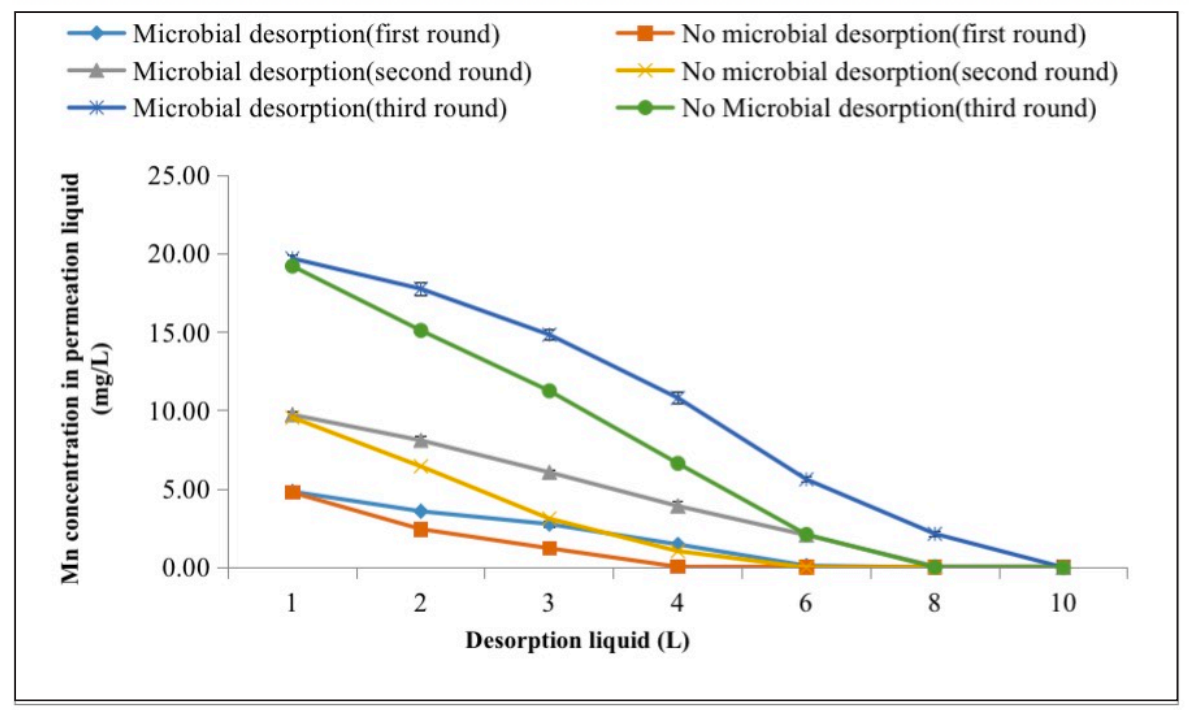

(b)

Fig. 4: Variation of Mn concentration in leaching liquid during adsorption and desorption.

can be completely eluted into the penetration liquid (Fig. 3b). In addition, compared with the soil column assisted by microorganisms, the Fe in the soil column without the assistance of selected bacteria are more likely to be desorbed and eluted. In the first round of desorption test, in the case of selected bacteria or not, the penetrant of Fe on the soil column is $7 \mathrm{~L}$ and $5 \mathrm{~L}$ respectively. In the second round of the desorption test, the penetrant of $\mathrm{Fe}$ on the soil column is $11 \mathrm{~L}$ and $9 \mathrm{~L}$ respectively. In the third round of the desorption test, the penetrant of $\mathrm{Fe}$ on the soil column is basically eluted. The finished penetration liquid is $15 \mathrm{~L}$ and $11 \mathrm{~L}$ respectively. In sum, the presence of the selected bacteria can slow down the desorption and elution of $\mathrm{Fe}$ in the soil.

With the increase of the penetration liquid volume, the concentration of $\mathrm{Mn}$ in the penetration liquid is on the rise and can reach the adsorption saturation state (Fig. 4a). At the same time, with the assistance of the selected bacteria, the adsorption capacity of soil for Fe in penetration liquid was improved. The adsorption of $\mathrm{Mn}$ on the soil column without the assistance of microorganisms would reach the saturation state faster. In the first round of the adsorption experiment, under the condition of selected bacteria or not, the breakthrough liquid of saturated adsorption of Mn was 14 
$\mathrm{L}$ and $7 \mathrm{~L}$ respectively. In the second round, the breakthrough liquid was $18 \mathrm{~L}$ and $13 \mathrm{~L}$ respectively. In the third round, the breakthrough liquid was $21 \mathrm{~L}$ and $15 \mathrm{~L}$ respectively (Fig. 4b). It can be seen that the selected bacteria also have a certain degree of synergistic effect on the adsorption of $\mathrm{Mn}$ in the leaching liquid.

In addition, three rounds of adsorption tests in this experiment have reached the adsorption saturation state, which shows that $\mathrm{Mn}$ in the leaching solution is more easily absorbed by the soil than Fe. Mn differs from Fe in that it is easy to form hydroxide colloid or settle in the soil. When the adsorption of Mn by the soil reached the saturation state, the concentration of $\mathrm{Mn}$ in the leaching liquid would not be reduced.

With the desorption process, the concentration of Mn in the penetration liquid decreased, and $\mathrm{Mn}$ adsorbed in the final soil column would be completely eluted into the desorption liquid. In addition, compared with the soil column assisted by microorganisms, $\mathrm{Mn}$ in the soil column without microbial assistance was more likely to be desorbed and eluted. In the first round of desorption test, in the case of selected bacteria or not, $8 \mathrm{~L}$ and $6 \mathrm{~L}$ of penetration liquid were basically eluted. In the second round, $10 \mathrm{~L}$ and $7 \mathrm{~L}$ of penetration liquid were basically eluted. In the third round, the finished penetration liquid was $10 \mathrm{~L}$ and $8 \mathrm{~L}$ respectively. It can be seen that the selected bacteria in the soil column slowed down the desorption rate of $\mathrm{Mn}$ in the soil column to a certain extent.

Compared with the desorption experiment of Fe, Mn adsorbed in soil was easier to be eluted. The reason may be that under the condition of $\mathrm{pH}>3.5$, Fe formed the colloid or precipitate of hydroxide easily, and Fe desorbed at the upper end of the soil column will form the hydroxide again and be detained in the process of migration to the lower end of the soil column. The adsorption of Fe on the soil column has not reached the adsorption saturation state in the adsorption process, so the desorption accompanied by the re-adsorption process was obvious. In contrast, the desorption process of Mn was easier, because Mn was more easily leached by amino acids, organic acids, and other metabolites secreted by microorganisms.

\section{CONCLUSIONS}

Through the simulation experiment, it is found that the selected bacteria (Pseudomonas putida, Lysinibacillus xylanilyticus, Lysinibacillus macroides, Bacillus simplex, Brevibacillus agri) has a certain degree of inhibition on the increase of $\mathrm{Fe}$ and $\mathrm{Mn}$ concentration in the $\mathrm{Fe}$ and $\mathrm{Mn}$ ore immersion liquid, and the inhibition on Mn was significantly stronger than that on Fe. The selected bacteria could improve the adsorption efficiency and capacity of free $\mathrm{Fe}$ and $\mathrm{Mn}$ in soil, and the desorption of soil iron and manganese by water was alleviated. Therefore, free Fe and $\mathrm{Mn}$ in coal aquifer and soil medium could also be immobilized by mixed bacteria The external environment was influenced by the interaction between the selected bacteria, Fe and Mn, including an increase in $\mathrm{pH}$, a drop in ORP, and a decrease in DO. These external environmental factors would directly affect the dissolution and redox reaction of $\mathrm{Fe}$ and $\mathrm{Mn}$.

To sum up, Fe, Mn, the selected mixed bacteria, and the external environment have a complex mutual response mechanism in the coal mine system. It is clear that the selected bacteria have a positive effect on the fixation of free Fe and $\mathrm{Mn}$. The mineral field may be a rich source of microorganisms, which have evolved various mechanisms to resist heavy metal stress and have other metabolic potentials, which can be used for repair and other processes of biotechnological significance. Consequently, suitable growth conditions can be provided for the mixed bacteria to improve the degradation and fixation of free $\mathrm{Fe}$ and $\mathrm{Mn}$ in the mining environment. It has a lot of implications for future research on iron and manganese pollution prevention and control.

\section{ACKNOWLEDGEMENTS}

This work was supported by the National Nature Science Foundation of China under Grant 41303059 for financial support.

\section{REFERENCES}

An, N., Fu, J. and Zhang, D., 2006. Isolation of iron and manganese removal bacteria and their oxidation performance. Shenyang Jianzhu Univ. J. Nat. Sci., 22: 989-994.

Bermudez, G.M.A., Jasan, R., Plá, R. and Pignata, M.L. 2012. Heavy metals and trace elements in atmospheric fall-out: Their relationship with topsoil and wheat element composition. J. Hazard. Mater., 213214: 447-456.

Bhuiyan, M.A.H., Parvez, L., Islam, M.A., Dampare, S.B. and Suzuki, S. 2010. Heavy metal pollution of coal mine-affected agricultural soils in the northern part of Bangladesh. J. Hazard. Mater., 173: 384-392.

Chen, T., Chen, Z., Jin, S., Li, H., Li, G. and Liang, H. 2015. Effect of pH value on the treatment of groundwater with a high concentration of iron, manganese, and ammonia nitrogen by the filter. Water Supply Drain. China, 31: 5-9.

Chen, Y., Chen, Z., Li, Z., Chen, G., Xiang, Y. and Feng, T. 2017. Research status and Prospect of remediation of manganese contaminated soil. J. Ecol. Environ., 26: 1451-1456.

Cui, S.J., Gu, L.K., Lian, Y.Y. and Li, G. 2010. Microbial remediation technology of coal mine wasteland. Metal Mine, 4: 182-185+188.

Fan, C., Gao, Y., Zhang, Y., Dong, W. and Lai, M. 2018. Remediation of lead and cadmium from simulated groundwater in loess region in northwestern China using permeable reactive barrier filled with environmentally friendly mixed adsorbents. Environ. Sci. Pollut. Res., 25: 1486-1496.

Giller, K.E., Witter, E. and Mcgrath, S.P. 1998. Toxicity of heavy metals to microorganisms and microbial processes in agricultural soils: A review. Soil Biol. Biochem., 30: 1389-1414. 
Guo, M.N., Yang, Z.P., Ma, J.J., Gao, J.X. and Jia, Z.B. 2014. Study on landscape ecological risk assessment of Yimin mining area. Resour. Ind., 16: 83-89.

Guo, X., Gu, J., Chen, Z.X., Gao, H., Qin, Q.J., Wei, S. and Zhang, W.J. 2012. Effects of heavy metal pollution on soil microbial community metabolism and enzyme activity in Tongchuan Coal Mine Area. J. Appl. Ecol., 23: 798-806.

Hauck, M., Paul, A. and Spribille, T. 2006. Uptake and toxicity of manganese in epiphytic cyanolichens. Environ. Exp. Bot., 56: 216-224.

Herndon, E., Brianne, Y., Hannah, F. and David, S. 2019. Iron and manganese biogeochemistry in forested coal mine spoil. Soil Sys., 3: 1-19.

Hou, D., Zhang, P., Wei, D., Zhang, J. and Luo, L. 2020. Simultaneous removal of iron and manganese from acid mine drainage by acclimated bacteria. J. Hazard. Mater., 3: 122-131.

Kovácik, J., Stěrbová, D., Babula, P., Zvec, P. and Hedbavny, J. 2014. Toxicity of naturally-contaminated manganese soil to selected crops. J. Agric. Food Chem., 62: 7287-7296.

Krishnan, K.P., Fernandes, S.O., Chandan, G.S. and Bharathi, P.A.L. 2007. Bacterial contribution to mitigation of iron and manganese in mangrove sediments. Marine Pollut. Bull., 54: 1427-1433.

Kulandaivel, S., Nagarajan, S., Priyanga, A., Saravanapandian, R. and Thangarani, A. 2015. Effect of cement dust pollution on microbial properties and alkaline phosphatase enzyme activity in the soil. Int. J. Curr. Microbiol. Appl. Sci., 4: 641-649.

Ling, W., Wu, X., Chen, Y., Liu, Q. and Guo, D. 2011. Screening of manganese removal microorganism and its characteristics. J. Central South Univ. Forest Sci. Technol., 31: 152-156.

Liu, W., Liu, S., Qin, W. and Tang, C. 2020. Pollution characteristics of surface water around the closed pit in the regional coal mining area of Guizhou Province. J. Subtrop. Resour. Environ., 15: 11-19.

National Standard of the People's Republic of China, 1990. GB 119061989 water quality determination of manganese potassium periodate spectrophotometric method State Bureau of technical supervision. http://english.mee.gov.cn/Resources/standards/water_environment/ method_standard2/200807/t20080710_125432.shtml

Patil, D.S., Chavan, S.M. and Oubagaranadin, J.U.K. 2016. A review of technologies for manganese removal from wastewaters. J. Environ. Chem. Eng., 4: 123-129.

Sasaki, K. 2009. Biomineralization of manganese by microorganisms and its application to environmental remediation. Shigen-Chishitsu, 55: 195-202.
Shafer, M.M., Toner, B.M., Overdier, J.T., Schauer, J.J., Fakra, S.C., Hu, S., Herner, J.D. and Ayala, A. 2012. Chemical speciation of vanadium in particulate matter emitted from diesel vehicles and urban atmospheric aerosols. Environ. Sci. Technol., 46: 189-195.

Sharma, J. and Fulekar M.H. 2009. identification of potential strain suttiauxella izard! dsm 9397 for remendiation of cadmium. Int J Biom. Bioinform., 4: 16-24.

Sorensen, M.A., Chase-Dunn, C.M. and Trumble, J.T. 2010. Chronic exposure to elevated levels of manganese and nickel is not harmful to a cosmopolitan detritivore, Megaselia scalaris (Diptera: Phoridae). Insect Sci., 16: 73-79.

Vazquez, M.C., Rodriguez, H.R. and Villafuerte, B.E.P. 2014. Risk: For whom? Representations of mining activity by different social actors in the Molango Manganese district of Hidalgo, Mexico. Risk Anal., 34: $28-43$.

Wang, F., Liu, C., Liang, X., Wei, Z. and Li, J. 2005. Separation of iron and manganese in sediments of Aha Lake, Guizhou Province. Environ. Sci., 11: 135-140.

Wang, Z., Wang, H., Li, X., Hou, X. and Liu, L. 2012. Research progress of removing iron and manganese from groundwater. Environ. Eng., 30: 48-51.

Yu, J., Zeng, G.M., Chen, Y.H., Yao, Z.Q. and Wang, F. 2004. Experimental study on biological removal of manganese from groundwater in Dongting Lake area. Hunan Univ. J. Nat. Sci., 7: 32-35.

Zerling, L., Hanisch, C. and Sciences, S.A.O. 2008. Iron as a New Water "Pollutant" in Central Germany. Euro-Mediterranean Information System on Know-How in the Water Sector, United Nations Convention to Combat Desertification, pp. 1-2.

Zhang, L., Luan, L., Wang, Y., Guan, S. and Guo, J. 2008. Analysis of ion-exchange test of underground water in Dalong Mine. Energy Environ., 6: 88-89.

Zhang, L.X., Li, Y., Li, C., Zhao, O.Y., Shi, W., Feng, S.D. and Yang, Z.X. 2017. Study on remediation of HMW-PAHs contaminated soil by Fusarium sp.-Starch-Alfalfa in the coal mine area. J. Soil Water Conserv., 1: 350-355.

Zhang, M.L. and Wang, H.X. 2009. Characteristics of soil heavy metal pollution around coal mine waste piles. Environ. Sci. Inform. Appl. Technol., 2: 90-92.

Zhou, C.C., Liu, G.J., Wu, S.C. and Lam, P.K.S. 2014. The environmental characteristics of usage of coal gangue in bricking-making: A case study at Huainan, China. Chemosphere, 95: 274-280. 